\title{
Comments on the GSSP for the basal Emsian stage boundary: the need for its redefinition
}

\author{
PETER CARLS, LADISLAV SLAVÍK \& JOSÉ I. VALENZUELA-RÍOS
}

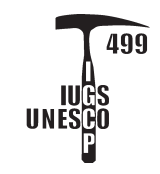

\begin{abstract}
The redefinition of the lower boundary of a traditional stage by means of a GSSP must be adapted as closely as practicable to the traditional boundary level because divergence between the original sense of the stage concept and name and the new GSSP creates confusing nomenclature. The present GSSP for the lower boundary of the Emsian Stage in the Zinzilban section (Kitab Reserve, SE Uzbekistan) is too low in the section to fulfill this requirement. Accordingly, a redefinition of the boundary of the lower Emsian by the International Subcommission on Devonian Stratigraphy (SDS) and the IUGS Commission on Stratigraphy is necessary. A new GSSP must be defined at a higher level and this could be done in strata of the present stratotype area. The stratigraphic correlation of the traditional Lower Emsian boundary and the GSSP is based on Mauro-Ibero-Armorican and Rheno-Ardennan benthic and pelagic faunas. - Key words: Pragian-Emsian GSSP, Inter-regional correlation, biostratigraphy, GSSP redefinition.
\end{abstract}

CARls, P., SlavíK, L. \& VALENZUEla-Ríos, J.I. 2008. Comments on the GSSP for the basal Emsian stage boundary: the need for its redefinition. Bulletin of Geosciences 83(4), 383-390 (1 figure). Czech Geological Survey, Prague. ISSN 1214-1119. Manuscript received July 3, 2008; accepted in revised form October 8, 2008; issued December 31, 2008.

Peter Carls, Institut für Umweltgeologie, Technische Universität Braunschweig, Pockelsstrasse 3, D-38023 Braunschweig, Germany • Ladislav Slavík (corresponding author), Institute of Geology AS CR, v.v.i., Rozvojová 269, CZ-16502 Praha, Czech Republic; slavik@gli.cas.cz•José Ignacio Valenzuela-Rios, Department of Geology, University of València, C/. Dr. Moliner 50, E-46100 Burjassot, Spain; Jose.I.Valenzuela@uv.es

The purpose of this paper is: 1. to review the reasons why the GSSP for the base of the Emsian Stage should be repositioned; 2. to suggest a new level for the base of the Emsian Stage that would be compatible with the historical usage of the Emsian and Pragian Stages. 3. to provide data and references in support of the recommended level.

Because:

1. The establishment of the current GSSP did not simply elaborate or refine the criteria by which the base of the Emsian could be recognized, it materially changed the range in time and stratal content of the stage. Therefore, if the present GSSP is maintained, the corresponding stage can no longer be called Emsian.

2. The present GSSP shortens the underlying Pragian, so that it hardly qualifies as a stage.

3. The present GSSP breaks the eognathodontid faunas in the middle and puts part of them in the Emsian in spite of the fact that they have always been considered Pragian.

The classical Emsian stage began at a level younger than that of the current GSSP. The difference has been estimated to be at least 4.5 ma (Carls 1999). Concomitantly, the middle and upper thirds of the original Pragian Stage and also the historical Siegenian from the upper half of the Early Siegenian onward would have to be called "Emsian". Where age assignments in older and recent literature are jointly evaluated, these circumstances cause considerable confusion - in addition to the particular difficulties of correlation due to the mid-Early Devonian conodont crisis and endemism in Europe.

Such problems are obvious, wherever the present basal GSSP of the Emsian is concerned. Also, conodont zones that were coined or modified in the course of the installation of this GSSP, are prone to be misunderstood. The points listed below are incompatible with the position of the present Emsian GSSP:

1. The evaluation of radiometry (Kaufmann 2006, text-fig. 9): The Esopus datum is assumed to be only 0.8 ma younger than the GSSP, although it follows after Global T-pulse Ib1 that starts at the entry of the Pol. exc. excavatus Zone, shortly before the traditional Emsian.

2. Calibration and synonymies of stages (Menning et al. 2006, pp. 324, 326, text-fig. 2): The Praha Fm. is shown to comprise hardly $2 \mathrm{ma}$; the "somewhat controversial taxon Eolinguipolygnathus dehiscens" is assumed to enter "lower than the top of the regional historical Pragian Stage", which cannot be proven - more probably, the taxon dehiscens s.s. is, at best, mid-Zlichovian in age, being probably a SE Australian endemic of which only the holotype is well documented.

3. The conodont zonation from pireneae Zone through gronbergi Zone is obscured: a.) see the latter item and, e.g., 
Yolkin et al. 1994. - b.) The "Middle excavatus Zone" has not been introduced duly; the index of this irregular subzone has been confounded with Pol. gronbergi and is much older. Due to the synonymisation, the dehiscens Zone was based by Klapper \& Johnson (1975) on the first occurrence of Pol. excavatus in bed 9 at Lone Mountain, central Nevada. When the identification of the zonal indicator changes because of taxonomic revision, the zone name also changes. Therefore, for the lowest Emsian Zone that has been used since Klapper and Johnson's paper, the proper zone name is excavatus Zone.

4. Sea-level fluctuations (Yolkin et al. 1997a, text-fig. 2) have been confounded as far as corresponding to the entry of Pol. kitabicus, the Siberian ASFA T-R cycle 3a does not correspond to the Euramerican cycle $\mathrm{Ib}$ of Johnson et al. (1985), but it is older.

5. Regional age assignments in Europe missed the actual GSSP. Morzadec et al. (2000, p. 119, text-fig. 4) did not correlate the Emsian GSSP, but all criteria aimed at the historical base of the Emsian. In the Appalachians (Ver Straeten \& Brett 2006, pp. 80, 81), the present GSSP cannot be correlated better than former reference levels; the Esopus base at Faunal Interval (F.I.) 9 is over 3 F.I. of Johnson (1977) younger than the present GSSP.

Since Carls \& Valenzuela-Ríos (1993), arguments and comments to these issues were presented in several submissions to the SDS and its relevant working groups. Herein, only basic biostratigraphic aspects are reviewed; additional facts in former submissions are still valid. This paper is focused on biostratigraphic constraints from the traditional type region of the Emsian; correlation with a closely comparable succession of faunas is demonstrated. It also contains remarks on cosmopolitan conodonts and dacryoconarids.

A new basal Emsian GSSP in the Zinzilban section must provide optimum practicability for correlations in biostratigraphic successions with cosmopolitan faunas worldwide.

\section{General relations and the equivalence of the present GSSP}

If the name Emsian is to be used for the upper stage of the Lower Devonian, the redefinition of the beginning of the Emsian and the future GSSP must correspond as closely as possible to the traditional level in the SE Eifel Hills, Germany (Mittmeyer 1974, Fuchs 1974) between older faunas with Acrospirifer primaevus and Hysterolites hystericus (Siegenian faunas of Saxler Fm., Herdorf "Gruppe") and younger faunas with Arduspirifer prolatestriatus (Emsian faunas, Ulmen "Gruppe").

Traditionally, the basal limit of the Emsian Stage was traced by and correlated according to this faunal change, but conodonts or other cosmopolitan taxa have not been found in its type region, However, the faunal change is correlated with the succession of brachiopod faunas in Celtiberia (Spain) where conodonts and dacryoconarids are also available allowing correlation with the Zinzilban and other sections. In the Zinzilban section, the level of the traditional basal Emsian boundary can be restricted to an interval of hardly $10 \mathrm{~m}$ that begins at $114 \mathrm{~m}$ above the present GSSP (see Fig. 1).

The distribution of Pragian conodonts (late Pelekysgnathus, late Masaraella; see below) and of brachiopods (Carls 1999) in Celtiberia permits the level of the present GSSP to be approximated and shows that the present Emsian GSSP is very much older than the traditional base of the Emsian ( $c f$. Fig. 1).

Also, it was shown that the present boundary GSSP is much older than the traditional German Siegenian-Emsian boundary (Carls \& Valenzuela-Ríos 1993, 2000, 2007; Carls 1999, 2007; Carls et al. 2007); it correlates with middle parts of the traditional Early Siegenian. According to conodonts, the present GSSP corresponds to the middle of J.G. Johnson's F.I. 5 in Nevada (close to faunal horizon COP II 295' of Murphy \& Matti 1983). This horizon coincides with the highstand of global T pulse Ia and is older than $\mathrm{T}$ pulse $\mathrm{Ib}$.

When the "dehiscens" boundary (see point 3 above) was selected for the beginning of the Emsian, it was assumed to be at the base of the F.I. 9 in Nevada and slightly below (see Johnson \& Klapper 1992) the start of global T pulse Ib. Actually, also these Nevadan markers are somewhat older than the traditional base of the Emsian in Germany, but the distance between the two Nevadan levels (F.I. 5 and F.I. 9-10) is much longer than the age difference between the so-called "dehiscens" boundary at the base of F.I. 9 (equivalent to $92 \mathrm{~m}$ ) in Zinzilban section where Pol. e. excavatus is reported to enter (Yolkin et al. 1994, p. 145, text-fig. 4b) and the traditional base of the Emsian in Germany.

The original Pragian and the traditional German Emsian overlap by ca $1 \mathrm{ma}$, but the level of the present GSSP is even more drastically older (order of magnitude of $5 \mathrm{ma}$ ) than the original end of the Pragian (boundary between Praha Fm. and Zlichov Fm. in the Prague Synform). It hardly allows $1 / 3$ of the originally conceived Pragian to survive.

\section{How the original boundary lost its meaning}

In this paper, we outline the history of the divergence between the traditional boundary, the original intentions of redefinition, and the definition of the present GSSP.

Rhenish brachiopods that characterize the traditional German base of the Emsian are correlated with the Celti- 
berian successions of brachiopods, conodonts and dacryoconarids (e.g., Guerichina). The Celtiberian conodonts are then correlated with those in the Zinzilban area $114 \mathrm{~m}$ and higher above the present GSSP. This correlation was further corroborated by Walliser \& Kim (2001), who showed that there are dacryoconarid faunas of the late original Pragian, which overlaps with the early Early Emsian, over $130 \mathrm{~m}$ above the present GSSP. In addition, we also report conodont and dacryoconarid evidence from the Prague Synform that supports these correlations (see Fig. 1).

Based on the above Introduction, we propose to review the Zinzilban section (and connected sections) for an appropriate level for the redefinition of the basal GSSP of the Emsian Stage.

\section{Circumstances that led to the inappropriate position of the present basal Emsian boundary GSSP}

For a revision of the Emsian GSSP it is convenient to recognize the reasons for its divergence from the tradition. We refer to biostratigraphic concepts that led toward the definition of the present GSSP, but we do not discuss the taxonomy of Pol. kitabicus, because this concerns a time slice about 4 ma older than the interval discussed in this paper.

The global biostratigraphic marker, at which initial proposals for the redefinition of the beginning of the Emsian Stage aimed, was the appearance of conodonts that were then identified and synonymized as "Polygnathus dehiscens Philip \& Jackson, 1967”. Klapper \& Johnson (1975) had recorded such material (including synonymized Pol. webbi excavatus Carls \& Gandl, 1969 = Pol. exc. excavatus) from near the top of the Kobeh Member in Central Nevada. Independently, also Johnson (1977) compared this level, by means of brachiopods, with the beginning of a level in fact corresponding with the traditional Emsian. Several taxa have been synonymized with Pol. dehiscens, but these synonymies are throughout questionable. These conodonts have been subject to divergent interpretations. E.g., the "evolutionary step" of the holotype of Pol. dehiscens has been compared to that "of Pol. perbonus or nothoperbonus" (Yolkin et al. 1994, p. 150). Indeed, the morphology of the oral side of the holotype of Pol. dehiscens is rather progressive ( $c f$. Mawson 1995, pl. 1, fig. 1). According to this criterion, a middle Zlichovian age cannot be excluded. Pol. dehiscens s.s. is probably a scarce SE Australian endemic species, as the characteristic oral side morphology of its holotype has not been found elsewhere. Accordingly, it cannot serve as an index for global zonation or for correlation of a GSSP. (See point 3 in Introduction.)
Primitive Polygnathus s.l. are generally characterized through large and deep, not inverted basal cavities. This aboral feature was long considered to warrant the identification of other taxa with Pol. dehiscens, in spite of the particular oral surface of the holotype, which is, in reality, more significant; but that was hardly considered. Due to the synonymizations, this lumped collective seemed to be cosmopolitan and apt as a zonal index taxon. Actually, many of the synonymized specimens are Pol. excavatus tota species. Because the prevailing concepts of Pol. dehiscens allowed a wide intra-specific variability of the outlines and the ornamentation of the oral side, rather different taxa were lumped in "dehiscens".

In addition to the problematic taxonomic concept of Pol. dehiscens s.l., there was a problematic concept of conodont zonation of the middle and late Pragian (the time of the middle and upper parts of the Praha Fm. in the Barrandian). The zonal index Pol. pireneae Boersma, 1973, as the oldest Polygnathus s.l. then known, was considered to mark the "latest Pragian" and to be the only cosmopolitan Polygnathus below the envisaged Pragian-Emsian boundary interval. Valenzuela-Ríos (1997) has already challenged this opinion and suggested a lower position (lower Pragian) for the entry of Pol. pireneae and that it was not related to classical Emsian faunas. This was already shown by Weddige (in Chlupáč et al. 1986) who found this taxon in a rather low part of the Praha Fm. This very low position of Pol. pireneae in the same section was later confirmed by further sampling (Slavík 2004). In the Zinzilban section it occurs with the last occurrences of the Pelekysgnathus serratus group that ranges only in the Lochkov and in early parts of the Praha Fm. as it does in Ibero-Armorica. The identification of Pol. pireneae may be qualified as problematic, because no mature $\mathrm{Pa}$ elements are known from its type stratum. In practice, specimens similar to the type material from rather old Pragian strata are usually assumed to be Pol. pireneae, even if they are not mature.

Most Polygnathus s.l. of assumed earliest Emsian age, and that differ from Pol. pireneae and from some endemic Central Asian species, were identified as Pol. dehiscens in the 1980s. So that several different taxa ranging between Pol. pireneae and Pol. dehiscens were hidden in the synonymy of the latter, and thus, the opinion became general that Pol. dehiscens descended directly from Pol. pireneae - although comparison of the oral sides of both holotypes would not support this opinion.

A section with both taxa in due succession (overlap) was sought for the installation of the Pragian-Emsian boundary GSSP at the thus assumed pireneae-dehiscens offspring. When such succession was thought to exist in the Zinzilban section (Yolkin et al. 1989), the present GSSP was proposed for this so-called "dehiscens boundary". But neither Pol. dehiscens s.s. nor other polygnathids of near-Emsian age (e.g., Pol. excavatus, Pol. lenzi) are 
present at the GSSP. First arguments against the deep position of the GSSP were forwarded by Carls \& Valenzuela-Ríos (1993) and subsequently more elaborated by Carls \& Valenzuela-Ríos (2000, 2007). The primitive species Pol. kitabicus Yolkin et al., 1994 was then erected for specimens from near the GSSP in the Zinzilban section. By Yolkin et al. (1989) this taxon had been considered as primitive Pol. dehiscens, but it is not closely related to Pol. dehiscens s.s., nor is it very similar to the synonymized Pol. excavatus. However, its distinction from Pol. pireneae has been debated, because mature Pol. pireneae is still unknown.

The GSSP was installed (Yolkin et al. 1997b) in spite of opposing opinions that criticized its very old stratigraphic level. This criticism is corroborated through the records of Pol. exc. excavatus that appears too high above the GSSP (Yolkin et al. 1994, text-fig. 4b). Even this entry is noticeably older than the traditional base of the Emsian. Nevertheless, in view of the distinction of Pol. kitabicus, it would have been understandable if the entry of Pol. exc. excavatus had been considered as the mark aimed at, because it was then evident that the Australian Pol. dehiscens had been confounded with it, when the "dehiscens" boundary was addressed in North America and Europe. Recent collecting at the Lone Mountain section originally used by Klapper \& Johnson (1975) verifies Pol. excavata as the species identified by them as Pol. dehiscens (collections and communication by M.A. Murphy).

Resuming, the conodont taxonomy and biostratigraphy on which the location of the GSSP in the Zinzilban section was founded since the proposal of 1989 implied several errors. Unfortunately, deficits in biostratigraphic information and taxonomic errors appeared to corroborate each other mutually. But evidently, the conodont biostratigraphy of the Pragian-Emsian transition was not yet consolidated. The international stratigraphical subcommission based its procedures on inadequate concepts. Submitted counter-arguments (Carls \& Valenzuela-Ríos 1993) were not recognized, when the installation of the present GSSP (Yolkin et al. 1997b) was decided and carried out.

\section{The age of the present GSSP level}

In the Field Guide of 1978 (Sokolov \& Garkovets 1978), it was stated that the end of the Madmon Fm. is not too different in age from the end of the Koněprusy Limestone of Bohemia. However, the local conditions differ. The Koněprusy Limestone ends under an unconformity due to local movements; late Pragian levels (in original sense) are not preserved; Pelekysgnathus ex gr. serratus was found in an upper part of the Koněprusy Ls. (Slavík et al. 2007, fig. 2), which hints at early Pragian age (Valenzuela-Ríos 1997).
Immediately under the present GSSP, there is a facies change (deepening) at the boundary between Madmon Fm. and Zinzilban Fm., due to a eustatic T-pulse. Whether this is accurately the global T-pulse Ia must still be checked, but it is distinctly older than the start of global T-pulse Ib that has been assumed erroneously. In the Zinzilban "Horizon", there still follow Bohemian brachiopods of original Pragian age like "Eospirifer" and Gorgostrophia; they confirm that the Madmon Fm. ends early in the original Pragian and that long Pragian time follows in the Zinzilban "Horizon". The following brachiopod distributions also hint at the age equivalence of the Madmon-Zinzilban boundary with early pre-Emsian levels: In Celtiberia (Carls 1999, p. 143; Carls \& Valenzuela-Ríos 2000) there occur 13 brachiopod taxa of the Bohemian Koněprusy Limestone in the interval from the top of the Nogueras Fm. through the lower third of the Santa Cruz Fm. (units d2c $\beta 8$ to d $3 b \beta 1$ ), ending with Sieberella sieberi. From the upper part of the Madmon Fm. S. cf. sieberi was reported and Sieberella sp. was figured from $108 \mathrm{~m}$ above the Madmon Fm. (Sokolov \& Garkovets 1978, pp. 13, 38, pl. 48, fig. 2). Therefore, the basal beds of the Zinzilban "Horizon" with the present GSSP must be correlated near the indicated interval in Celtiberia. In Celtiberia, it is independently demonstrated that the Koněprusy taxa are considerably older than the traditional base of the Emsian and the original end of the Pragian (Carls 1987, 1999; Carls \& Valenzuela-Ríos, 2000, 2007).

Regardless of the debated Polygnathus s.l. at the present GSSP, its conodont biostratigraphic age is unambiguously indicated through some age-diagnostic taxa that exist very closely below and above the GSSP and were recorded by Yolkin et al. (1989, text-fig. 1). (The possibly endemic Central Asian Polygnathus s.l. some of which have not been found in other continents, are not considered here.) As these non-Polygnathus conodonts have not been figured, their specific identifications might be questioned by critical readers. Therefore, in order to prevent fruitless discussions, most of these conodonts are here listed in open terms. In these terms they can hardly be misidentified but still allow the dating of the interval including the GSSP:

eognathodontids (closely below the GSSP)

Polygnathus pireneae

Pedavis sp.

Pelekysgnathus e.g. serratus

Even these open terms warrant the unambiguous reference to a short interval that must be correlated below the middle of the original Pragian (Valenzuela-Ríos 1997). Elsewhere, conodonts comparable to these taxa do not range above the middle of the original Pragian. Pelekysgnathus e.g. serratus ends in Ibero-Armorica close to a last Masaraella pandora beta morphotype (Guadarrama MS12e), before the entry of Icriodus simulator, and in Bohemia it disappears in the lower third of the Praha Fm. 


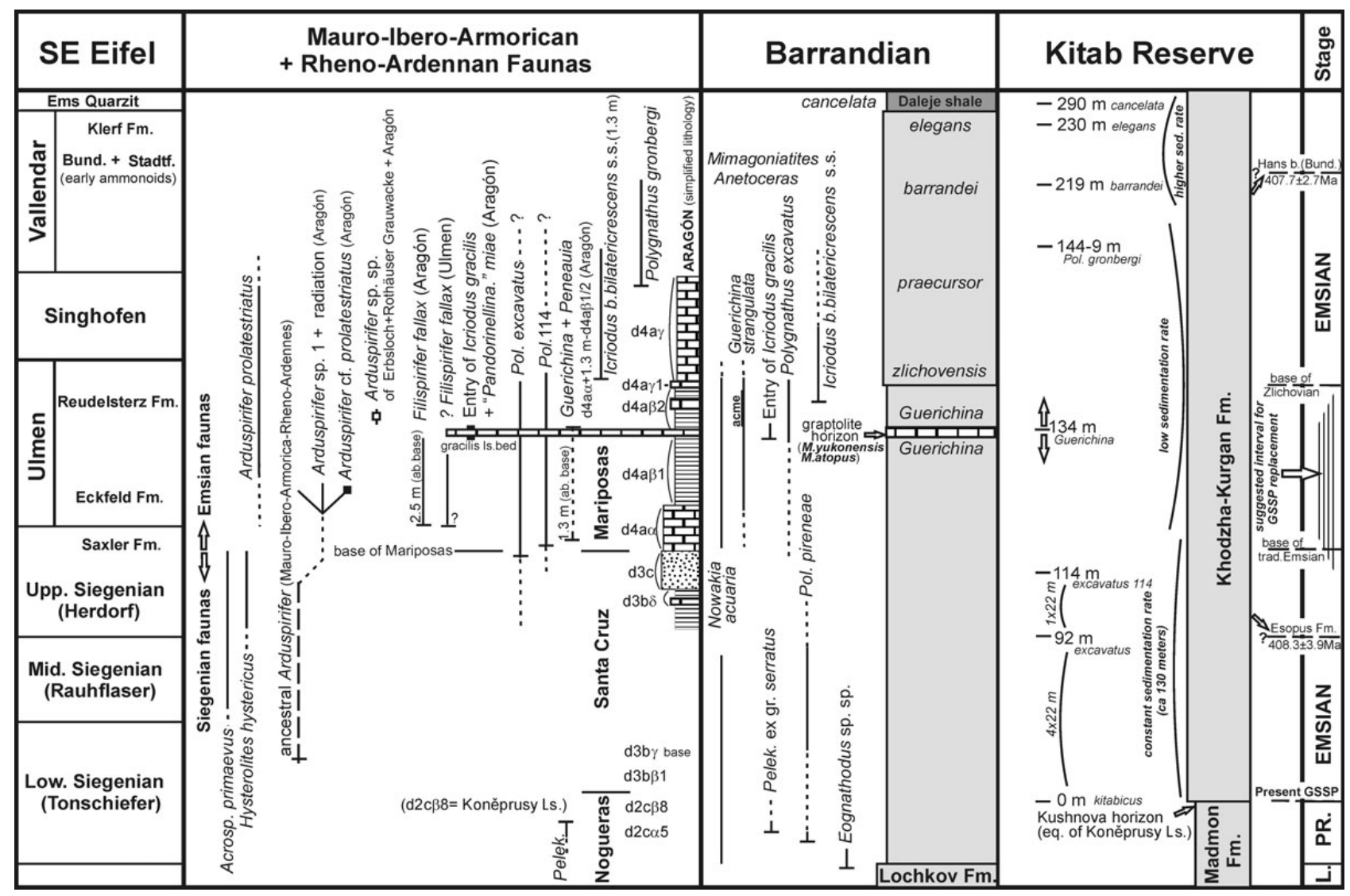

Figure 1. Simplified inter-regional correlation scheme showing the distribution of cosmopolitan taxa and vertical arrangement of lithostratigraphic units. The relative position of important levels in relation to the present basal Emsian GSSP is marked on the right. The vertical extensions of lithostratigraphic units and taxon ranges are not to scale, but are zoomed up near the traditional base of the Emsian. The measured radiometric ages from the basal Esopus and from the Bundenbach Hans Bed are too close to each other; they should differ by about 2.5 to 3 ma.

Simplified lithological column for Aragón covers lithostratigraphic units and sub-units from the upper part of the Nogueras Fm. (d2c $\alpha 5$, d2c $\beta 8$ ), the mid-

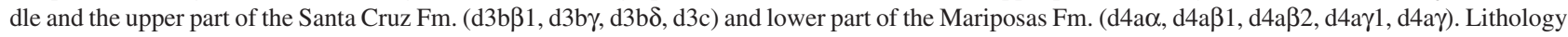
and thickness: Santa Cruz Fm. d3b $\delta$ - shales with limestone intercalations, ca 25m; d3c - deltaic shales and sandstones, ca 100 m; Mariposas Fm. $\mathrm{d} 4 \mathrm{a} \alpha$ - limestones, $8 \mathrm{~m}$; d4a 1 - shales, up to $13 \mathrm{~m}$; "gracilis 1s. bed" - 0.1-0.5 m; d4a $\beta 2$ - shales with limestone intercalations, less than $10 \mathrm{~m}$; d4a - limestones, ca $18 \mathrm{~m}$. For detailed description of lithology see Carls (1988).

The column for Kitab Reserve is according to Yolkin et al. (1994, text-fig. 4b) and Sokolov \& Garkovets (1978); it shows positions of important taxa from several sections in the Zinzilban area including the Zinzilban section. These published data are used for correlation in this paper.

Simplified lithology for Barrandian and Kitab Reserve: light grey colour indicate predominating shallow-water to pelagic carbonate successions. Abbreviations: ab. base - above base, trad. Ems. - traditional Emsian, Bund. - Bundenbach, eq. - equivalent, Fm. - Formation, Hans b. (Bund.) - Hans bed (Bundenbach), 1s. - limestone, L. - Lochkovian, Low. - Lower, Mid. - Middle, PR. - Pragian, Stadtf. - Stadtfeld, Upp. - Upper, Acrosp. - Acrospirifer, Pelek. - Pelekysgnathus, M. - Monograptus, Pol. - Polygnathus.

From the Požáry section, Pol. pireneae was reported from only $10 \mathrm{~m}$ above the Lochkovian-Pragian boundary (Chlupáč et al. 1986).

This independent age assignment is corroborated by the fact that Pol. exc. excavatus enters in the Zinzilban section as high as $92 \mathrm{~m}$ above the GSSP. In Celtiberia it is known from beds just older than original Emsian and from early Early Emsian. This underlines the length of the interval between the present GSSP and the original base of the Emsian.

Thus, independent of each other, two sets of age-relevant conodonts and, additionally, several brachiopods of Bohemian biofacies indicate a long-term pre-Emsian age of the present GSSP.

\section{The traditional base of the Emsian in Germany, relevant Spiriferacea, and associated conodonts and dacryoconarids in Celtiberia}

The traditional base of the Emsian is located in the SE Eifel Hills in Germany, in thick siliciclastic shallow neritic deposits long referred to as the Rhenish Facies. There, the top of the Saxler Fm. marks the top of the Herdorf "Gruppe" that represents the historical upper Siegenian Substage. The overlying base of the Eckfeld Fm. marks the base of the Ulmen "Gruppe" (traditional lower lower Emsian) and represents the beginning of the traditional Emsian Stage. Shelly 
faunas with characteristic Spiriferacea distinguish the older from the younger unit (Mittmeyer 1974, Fuchs 1974).

The historical base of the Emsian in Belgium was practised at a younger level, corresponding to the end of the Ulmen "Gruppe" (Godefroid \& Stainier 1982). This level is close to the base of the Zlichovian. Here it is not considered in the GSSP context, because no cosmopolitan taxon of Polygnathus s.l. enters at this level and because this level is rather young and would result in too short an early Emsian. (The latter argument is independent of the fact that the numerical age difference between the Esopus and the Bundenbach radiometric data, $0.6 \mathrm{ma}$, is too short to bracket ca $90 \%$ of the traditional Early Emsian [see Kaufmann 2006].)

The uppermost occurrences of Acrospirifer primaevus and Hysterolites hystericus, whose ranges are considered well established, mark the end of the Siegenian. On the other hand, the beginning of the traditional Emsian has been characterized variously by the entries of several Spiriferacea. In spite of this variety of proposals, the envisaged lithic boundary level was constant. Of the Spiriferacea, Euryspirifer, Arduspirifer and Filispirifer have the best potential for the correlation of the Rhenish succession with Ibero-Armorican successions. Jansen (2001 and ongoing work) has reviewed these genera in detail. An early radiation of Arduspirifer allows a detailed correlation because primitive Arduspirifer had developed since late Early Siegenian time in Mauro-Ibero-Armorica and since the Middle Siegenian also in the Rheno-Ardennan basin. However, in the Rheno-Ardennan Siegenian, the taxa are scarce and were hardly applied for correlation.

In Celtiberia, these spiriferacean genera are more abundant and occur with cosmopolitan conodonts and dacryoconarids in the Mariposas Fm. where Arduspirifer sp. 1 (= "Arduspirifer arduennensis antecedens Morphotyp I" of Schriefer 1988, pl. 1, figs 1-9) is common throughout its basal submember (d4a-alpha) of latest Siegenian to earliest Emsian time. It overlaps with Guerichina sp. from $1.3 \mathrm{~m}$ above the base of the formation onward. In the Prague Synform, Guerichina ranges mainly in the late Pragian (in the original sense) and fades in the earliest Zlichovian; and in Germany it is known below and above the Erbsloch Grauwacke of early Early Emsian age. After Arduspirifer sp. 1, radiation within Arduspirifer intensified and produced several divergent taxa. In Celtiberia, a high part of unit d4a-beta- 1 of the Mariposas Fm. bears Ard. cf. prolatestriatus. In that time interval in the SE Eifel Hills, Ard. prolatestriatus became the predominant index within the Ulmen "Gruppe". These occurrences are virtually coeval; the slight morphologic differences can be attributed to differences in biofacies and preservation rather than differences in time of origin.

Consequently, the range of the Celtiberian Arduspirifer sp. 1 is very close to the traditional base of the Emsian, and the early part of its range would probably have been termed final Siegenian.

The first German spiriferid, Filispirifer fallax that is not known from the Siegenian occurs from $2.5 \mathrm{~m}$ above the base of the Mariposas Fm. onward. This position supports the correlation of Arduspirifer sp. 1 as ranging across the traditional base of the Emsian. The shelly fauna of the top bed of the Santa Cruz Fm. and the base of the Mariposas Fm. just below Filispirifer fallax has only one taxon (Crinistrophia), which elsewhere is delimited to the classic Emsian. This sequence of faunal elements supports the pre-Emsian age of these beds at the formation boundary.

The transitional bed between the Santa Cruz and Mariposas Formations (from calcareous sandstones to arenaceous limestones, both with the same fauna, up to $50 \mathrm{~cm}$ thick) is the lowest bed that also bears conodonts. It is the type stratum of Pol. exc. excavatus. Its upper part contains also Pol. excavatus ssp. 114. Consequently, it is as old as the entry of Pol. excavatus ssp. 114 in the Zinzilban section. The taxon here termed Pol. excavatus ssp. 114 was characterized by Yolkin et al. (1994, p. 148) and was recorded from $114 \mathrm{~m}$ above the kitabicus GSSP onward, but it was identified as Pol. "excavatus gronbergi" and was considered as the index for their "Middle excavatus Zone". This was induced through changes of the posterior bottom of the basal cavity and through incipient ribs crossing the tongue (features also seen in the Mariposas Fm.). In the Mariposas Fm., Icriodus celtibericus and Icriodus sigmoidalis enter together with Pol. excavatus ssp. 114.

In Europe (e.g., Aragón, Barrandian), Pol. gronbergi and the gronbergi Zone are recognized at younger, intra-Zlichovian levels, i.e. above the range of Guerichina. In the Zinzilban section atlas (Sokolov \& Garkovets 1978), Pol. gronbergi was figured (pl. 75, figs 4, 5) from $144 \mathrm{~m}$ and $149 \mathrm{~m}$ above the GSSP.

The true origin of Pol. exc. excavatus cannot be identified in Celtiberia, due to lack of appropriate limestones below the basal bed of the Mariposas Fm. Although this bed is pre-Emsian in traditional sense, the entry of Pol. excavatus ssp. 114 in the Zinzilban section might be considered for the choice of a GSSP because it can only be slightly older than the traditional boundary. This level may well be within the range error associated with the correlation from the Rhineland to Spain. In addition, this difference is of an order of magnitude much smaller than the inferred difference in levels between the GSSP and the traditional Emsian lower boundary. A slightly younger entry of a cosmopolitan taxon would also be welcome for the position of a new GSSP.

Guerichina and Peneauia are still found at the entry of "Pandorinellina" miae s.s. and Icriodus gracilis in the limestone level at the base of unit d4a-beta-2 of the Mariposas Fm.; these are immediately below Arduspirifer sp. sp. that occur also in the Erbsloch Grauwacke and 
Rothäuser Grauwacke of early Early Emsian age (Ulmen). In the Prague Synform, the youngest strata of the Praha Fm. (i.e., around the "graptolite interval" that is present in the NW limb of the Prague Synform) bear these conodonts and Guerichina. These conditions warrant additional controls of the biostratigraphy in the European type regions of the stages concerned.

\section{Conclusions}

The present GSSP of the Pragian-Emsian boundary in the Zinzilban Gorge section (Kitab Reserve, Zerafshan, Uzbekistan) cannot be maintained for the following reasons:

1. It adds most of the historical Siegenian to the Emsian and reduces the Pragian to notably less than half its original duration and has caused more problems in correlation than it has solved. If it is maintained, it will continue to cause confusion and the original terms Emsian and Pragian will have to be abandoned.

2. A new basal Emsian GSSP in the Zinzilban section could provide optimum practicability for correlations in worldwide cosmopolitan biostratigraphic successions. The appropriate level for the new basal Emsian global stratotype is the origin of Polygnathus excavatus ssp. 114. This would be $114 \mathrm{~m}$ above the present GSSP (i.e. early within the prime of the genus Guerichina). This change is necessary in order to provide the means for accurate identification of the Pragian-Emsian boundary.

\section{Acknowledgements}

The manuscript was read critically by Michael A. Murphy and Alan E.H. Pedder; they provided many useful suggestions to the text. We have profited largely from their comments and thank them very much. The Alexander von Humboldt Foundation awarded a fellowship to Ladislav Slavík and supported his stay at the Technische Universität Braunschweig in summer 2008. The paper was developed with the support of the Grant agency of the ASCR (project No. B300130613) and of the Institute of Geology ASCR, v.v.i. (Institutional project: AV0Z30130516). It represents a contribution to the UNESCO/IGCP project No. 499 (DEVEC).

\section{References}

CARLS, P. 1987. Ein Vorschlag zur biostratigraphischen Redefinition der Grenze Gedinnium/Siegenium und benachbarter Unter-Stufen. Courier Forschungs-Institut Senckenberg 92, 77-121.

CARLS, P. 1988. The Devonian of Celtiberia (Spain) and Devonian Paleogeography of SW Europe. In MCMILLAN, N.J., EMBRY, A.F. \& GLASS, D.J. (eds) Devonian of the WorldProceedings of the $2^{\text {nd }}$ International Symposium on the Devo- nian System, Calgary 1987, Canadian Society of Petroleum Geologists Memoir 14(1), 421-466.

CARLS, P. 1999. El Devónico de Celtiberia y sus fósiles, 101-164. In GÁMEZ-VinTANED, J.A. \& LiÑán, E. (eds) Memorias de las VI Jornadas Aragonesas de Paleontología, 25 años de Paleontología Aragonesa, Homenaje al Prof. Leandro Sequeiros, Zaragoza.

CARLS, P. 2007. Faunal and cyclicity controls for the calibration of the early Devonian, 20-21. In OVER, D.J. \& MORROw, J. (eds) Subcommission on Devonian Stratigraphy and IGCP 499 Devonian Land Sea Interaction, Eureka, NV, 9.9.-18.9. 2007, SDS \& IGCP 499 Eureka, NV 2007 Program and Abstracts. San Diego State University \& SUNY-Geneseo, Eureka.

CARLS, P. \& VALENZUELA-RÍOS, J.I. 1993. Materials near the redefined Base of the Emsian Stage. International Union of Geological Sciences, International Commission on Stratigraphy, Subcommission on Devonian Stratigraphy Newsletter No. 10, p. 30, 1 table. Arlington, Texas.

CARLS, P. \& VALENZUELA-Ríos, J.I. 2000. Faunas, correlations, various boundaries, and opinions concerning the early Emsian sensu lato and a cancellata boundary. Web page of SDS Emsian Working Party, http://www.es.mq.edu.au/ mucep/emsian/carls_and_rios/carls_and_rios.htm

CARls, P. \& VAlEnZUEla-Ríos, J.I. 2007. From the Emsian GSSP to the early late Emsian-correlations with historical boundaries. Newsletter of the International Subcommision on Devonian Stratigraphy (SDS) 22, 24-28.

CARLS, P., SlavíK, L. \& VAlenZUela-Ríos, J.I. 2007. Succession of Biostratigraphic marks for the Early Emsian, 22-23. In OVER, D.J. \& MORROW, J. (eds) Subcommission on Devonian Stratigraphy and IGCP 499 Devonian Land Sea Interaction, Eureka, NV, 9.9.-18.9. 2007 SDS \& IGCP 499 Eureka, NV 2007 Program and Abstracts. San Diego State University \& SUNY-Geneseo, Eureka.

ChlupÁČ, I., Hladil, J. \& LuKEŠ, P. 1986. Barrandian-Moravian Karst, 1-62. Guidebook of the Field Conference of the International Subcommission on the Devonian Stratigraphy. Ústřední ústav geologický, Praha.

FUCHS, G. 1974. Das Unterdevon am Ostrand der Eifeler Nordsüd-Zone. Beiträge zur naturkundlichen Forschung in Südwestdeutschland Beihefte, Beiheft 2, 1-163.

GODEFROID, J. \& STAINIER, P. 1982. Lithostratigraphy and biostratigraphy of the Belgian Siegenian on the south and southeast borders of the Dinant Synclinorium. Courier Forschungs-Institut Senckenberg 55, 139-163.

JAnSEn, U. 2001. Morphologie, Taxonomie und Phylogenie unter-devonischer Brachiopoden aus der Dra-Ebene (Marokko, Prä-Sahara) und dem Rheinischen Schiefergebirge (Deutschland). Abhandlungen der senckenbergischen naturforschenden Gesselschaft, 1-554.

JOHNSON, J.G. 1977. Lower and Middle Devonian Faunal Intervals in Central Nevada based on brachiopods, 16-32. In MurPhy, M.A., BERRY, W.B.N. \& SANDBERG, C.A. (eds) Western North America: Devonian, University of California, Riverside Campus, Museum Contribution 4. 
Johnson, J.G., KlapPeR, G. \& SAndBerg, C.A. 1985. Devonian eustatic fluctuations in Euramerica. Geological Society of America Bulletin 96, 1349-1359.

DOI 10.1130/0016-7606(1985)96<567:DEFIE >2.0.CO;2

KaufmanN, B. 2006. Calibrating the Devonian Time Scale: A synthesis of U-Pb ID-TMS ages and conodont stratigraphy. Earth-Science Reviews 76, 175-190. DOI 10.1016/j.earscirev.2006.01.001

KLAPPER, G. \& JOHNSON, D.B. 1975. Sequence of conodont genus Polygnathus in Lower Devonian at Lone Mountain, Nevada. Geologica et Palaeontologica 9, 63-83.

MAWSON, R. 1995. Early Devonian polygnathid conodont lineages with special reference to Australia. Courier Forschungs-Institut Senckenberg 182, 389-398.

Menning, M., Alekseev, A.S., Chuvashov, B.I., DavyDOV, V.I., DEVUYST, F.X., FORKE, H.C., GRUNT, T.A., HANCE, L., HeCKel, P.H., IZOKH, N.G., JIN, Y.G., JONES, P.J., Kotlyar, G.V., KozUr, H.W., Nemyrovskaya, T.I., SCHNEIDER, J.W., WANG, X.D., WEDDIGE, K., WEYER, D. \& WORK, D.M. 2006. Global time scale and regional stratigraphic reference scales of Central and West Europe, East Europe, Tethys, South China, and North America as used in the Devonian-Carboniferous-Permian Correlation Chart 2003 (DCP 2003). Palaeogeography, Palaeoclimatology, Palaeoecology 240, 318-372. DOI 10.1016/j.palaeo.2006.03.058

MitTMEYER, H.G. 1974. Zur Neufassung der Rheinischen Unterdevon-Stufen. Mainzer geowissenschaftliche Mitteilungen 3, 69-79.

Morzadec, P., Brice, D., Cygan, C., Feist, R., Majeste Menjoulas, C., Paris, F. \& Racheboeuf, P.R. 2000. The Devonian of France: a tentative tie with the GSSP of the Devonian stages. Courier Forschungs-Institut Senckenberg 225, $115-129$.

MURPHY, M.A. \& MATTI, J.C. 1982. Lower Devonian conodonts (hesperius-kindlei zones), central Nevada. University of California Publication in Geological Sciences 123, 1-83.

PHILIP, G.M. \& JACKSON, J.H. 1967. Lower Devonian subspecies of the conodont Polygnathus linguiformis Hinde from southeastern Australia. Journal of Paleontology 41, 1262-1266.

SCHRIEFER, U. 1988. Entwicklung von Arduspirifer (Brachiopoda, Spiriferacea) im Bereich der Grenze Siegenium/Emsium in Süd-Aragón (Spanien). 55 pp. Unpublished diploma thesis, Faculty of Natural Sciences, Technische Universität Braunschweig.

SLAVÍK, L. 2004. A new conodont zonation of the Pragian in the Stratotype area (Barrandian, central Bohemia). Newsletters on Stratigraphy 40(1-2), 39-71. DOI $10.1127 / 0078-0421 / 2004 / 0040-0039$

SlavíK, L., VAlenzuela-Ríos, J.I., Hladil, J. \& CaRls, P. 2007. Early Pragian conodont-based correlations between the Barrandian area and the Spanish Central Pyrenees. Geological Journal 42, 499-512. DOI 10.1002/gj.1087

SOKOLOV, B.S. \& GARKOVETS, V.G. Eds 1978. Type sections of the Lower and Middle Devonian boundary beds in the Middle Asia. A Guide to Field Excursions. Atlas of the paleontological plates. Supplement to A Guide of the Field Excursions. 55 pp. Field session of the International Subcommission on Devonian Stratigraphy. Samarkand, Tashkent.

VAlenZuela-Ríos, J.I. 1997. Can Polygnathus pireneae be the index of a standard conodont Zone? Newsletters on Stratigraphy 33(3), 173-179.

Ver Straeten, C.A. \& Brett, C.E. 2006. Pragian to Eifelian strata (Middle Lower to lower Middle Devonian), northern Appalachian Basin - stratigraphic nomenclatural changes. Northeastern Geology \& Environmental Sciences 28(1), 80-95.

WALLISER, O.H. \& KIM, A.I. 2001. On lowermost Emsian tentaculites from the Zinzilban boundary section and their utility for correlation. Document submitted to the Subcommission on Devonian Stratigraphy. May 2001, 2 pp. Frankfurt a. M.

YoLKIN, E.A., APEKINA, L.S., ERINA, M.V., IZOKH, N.G., KIM, A.I, TALENT, J.A., WALliSER, O.H., WeDdige, K., WerNER, R. \& ZIEGLER, W. 1989. Polygnathid lineages across the Pragian-Emsian boundary, Zinzilban Gorge, Zerafshan, USSR. Courier Forschungs-Institut Senckenberg 110, 237-246.

Yolkin, E.A., GRATSIANOva, R.T., IZOKH, N.G., YAZIKOV, A.Y. \& BAKHAREV, N.K. 1997a. Devonian sea-level fluctuations on the south-western margin of the Siberian continent. Courier Forschungs-Institut Senckenberg 199, 83-98.

YolkIN, E.A., KIM, A.I., WedDIGE, K., TALENT, J.A. \& HousE, M.R. 1997b. Definition of the Pragian/Emsian Stage boundary. Episodes 20, 235-240.

YolKin, E.A., WedDige, K., IZOKH, N.G. \& ERINA, M.V. 1994. New Emsian conodont zonation (Lower Devonian). Courier Forschungs-Institutut Senckenberg 168, 139-157. 